\title{
Towards a more effective strategy for COVID-19 prevention (Review)
}

\author{
ANNA K. SZKARADKIEWICZ-KARPIŃSKA ${ }^{1}$ and ANDRZEJ SZKARADKIEWICZ ${ }^{2}$ \\ ${ }^{1}$ Department of Preclinical Conservative Dentistry and Preclinical Endodontics, University of Medical Sciences, \\ 60-812 Poznań; ${ }^{2}$ Institute of Health and Physical Culture, State Higher Vocational School, 64-100 Leszno, Poland
}

Received September 4, 2020; Accepted October 28, 2020

DOI: $10.3892 / \mathrm{etm} .2020 .9465$

\begin{abstract}
At the end of 2019, a new disease, similar to severe acute respiratory syndrome (SARS) associated with SARS-CoV was reported in Wuhan, China. It was quickly discovered that the etiological factor of the new disease (COVID-19) was a previously unknown SARS coronavirus 2 (SARS-CoV-2). The global spread of of COVID-19 has lead to the declaration of a pandemic status in 2019-2020 as declared by the World Health Organization and Public Health Emergency of International Concern. SARS-CoV-2 characterizes with high epidemic potential and is effectively disseminated between humans. SARS-CoV and SARS-CoV-2 are closely related pathogens. Their prime route of distribution is air-droplet transmission. Combating infectious diseases disseminated by inhalation is very difficult, and mainly relies on the use of vaccines. However, despite the lack of an effective anti-SARS-CoV vaccine and specific antiviral drugs, the strict sanitary procedures proved to be sufficient to stop the SARS epidemic in June 2003. However, epidemic research has indicated that SARS-CoV-2 is transmitted in humans significantly more effectively than SARS-CoV; therefore, the COVID-19 pandemic continues to expand. This indicates that the so far anti-epidemic activities to control COVID-19 are insufficient. In the current review, the possibility of using interferon $\alpha$ (IFN- $\alpha$ ) as a preventive agent of COVID-19 is discussed. The current data concerning anti-COVID-19 vaccines and specific drugs against SARS-CoV-2 are also discussed. The aim of the current review is to contribute to the introduction of a more efficient strategy in the protection of the human population against COVID-19.
\end{abstract}

Correspondence to: Professor Andrzej Szkaradkiewicz, Institute of Health and Physical Culture, State Higher Vocational School, 5 Mickiewicza Street, 64-100 Leszno, Poland

E-mail: szkaradkiewicza@poczta.onet.pl

Key words: SARS coronavirus 2, COVID-19, pandemic, public health, immunity, vaccines, antivirals drugs, interferon

\author{
Contents \\ 1. Introduction \\ 2. Anti-COVID-19 vaccine \\ 3. Anti-SARS-CoV-2 drugs \\ 4. Interferon (IFN) \\ 5. Conclusion
}

\section{Introduction}

SARS-CoV-2 is characterized with high epidemic potential. Since the beginning of 2020 it has been quickly transmitting among people in the world, usually causing an acute respiratory disease of the respiratory system - COVID-19 (1). The occurrence of the new disease, resembling severe acute respiratory syndrome (SARS) was identified at the end of 2019 in Wuhan, China (2-4). The incubation period of the disease is 2-14 days, usually 3-7 days. The earliest common symptoms of COVID-19 are fever, cough and dyspnea (5). Recently presented meta-analysis report their occurrence as follows: $87.3,58.1$ and $38.3 \%$, respectively (6). It is noted that the typical clinical features are interstitial pneumonia $(75.7 \%)$ and ground glass opacification (69.9\%) in chest X-ray (5). The manifestations of the disease often include the symptoms from the gastrointestinal tract, like diarrhea, nausea/vomiting and abdominal pain. Meta-analysis reported occurrence of these symptoms as follows: 9,6 and $4 \%$, respectively (7). In severe cases COVID-19 may cause progressive pneumonia, acute respiratory distress syndrome (ARDS), multiple organ failure, and death. In the result of rapidly spreading SARS-CoV-2, until March 13, 2020, infections with the new coronavirus were reported in the total of 138 countries on all continents (except for Antarctica), with over 145 thousand reported infections including over 5 thousand deaths (8). Due to the global outbreak of COVID-19 the pandemic status 2019-2020 was declared by the World Health Organization (WHO) and the Public Health Emergency of International Concern (PHEIC) on March 11, 2020 (9,10). Whereas, much earlier strict sanitary procedures, including isolation of the sick and mandatory quarantine for exposed persons (contacts) were introduced. Despite the anti-epidemic proceedings, the global count of COVID-19 patients has been increasing, and according to Center for Systems Science and Engineering (CSSE), exceeded 
26 million people, including over 864 thousand deaths (as at September 3, 2020) (11). It is estimated that approximately $10 \%$ of global population may have been infected. The prime way of SARS-CoV-2 dissemination among humans, similarly to SARS-CoV, is air-droplet transmission (contagiousness of both viruses survives in the air up to $3 \mathrm{~h}$ ). Moreover, the viruses can be transmitted through direct contact with infected persons or indirectly via coronavirus contaminated materials/objects $(12,13)$. SARS-CoV and SARS-CoV-2 are closely related pathogens. They demonstrate around $80 \%$ homology in genomic sequence of nucleotides and they share highly conserved receptor binding domain for their $\mathrm{S}$ proteins $(14,15)$. Those viruses caused acute infection in humans through the same target receptors: angiotensin-converting enzyme 2 (ACE2) together with transmembrane serine protease 2 (TMPRSS2) $(16,17)$. It is commonly known that controlling infectious diseases disseminated by respiratory ways is very difficult, and mainly relies on the use of vaccines. However, despite the lack of an effective anti-SARS-CoV vaccine and antiviral drugs, strict sanitary procedures proved to be sufficient to stop SARS epidemic occurring from November 2002 till June 2003 in China, and subsequently in 36 other countries of the world (on 3 continents in total) (18-20). On the other hand, epidemic research show that SARS-CoV-2 is transmitted in humans more effectively than SARS-CoV, the transmission of SARS-CoV-2 may occur prior to symptomatic disease (21-23). In the light of such data it may be concluded that the anti-epidemic activities aiming at combating COVID-19 are insufficient and require new approach to preventing this disease in high-risk populations.

\section{Anti-COVID-19 vaccine}

Quick progress of works on anti-COVID-19 vaccine allows expecting its availability for large-scale distribution by the end of 2020. According to WHO data, 28 candidates vaccines are currently in clinical evaluation, and for 8 of them phase 3 tests are pending (24). The last group contains traditional preparations containing whole-inactivated virus, and genetic, including recombinant adenovirus type 5 vector, encoding single S-protein of SARS-CoV-2 (25). It is suspected that vaccine candidates involve the full-length $S$ protein which may induce both neutralizing and non-neutralizing (with the wrong specificity) antibodies. The vaccine should induce long-lasting active acquired immunity (humoral and cellular) against a specific pathogen, effectively preventing the development of a disease caused by that pathogen (26-28). Vaccines containing inactivated viruses or nucleic acids encoding a specific viral protein may induce high level of specific IgM and IgG in blood. However, they usually do not stimulate cellular immunity related to cytotoxic T lymphocytes (CTL) which effectively prevent viral infection spreading. In the consequence of use of the vaccine, it is finally expected that an immune population barrier against the specific infections disease will develop, and in the result will eradicate it. Considering the data presented above, it seems that the effectiveness of none of the above preparations will be satisfactory.

The basic condition of a common use of a vaccine in healthy people is safety. At present, there is a risk that vaccination could make subsequent SARS-CoV-2 infection more severe (29-31). There are two different antibody-mediated syndromes. One is antibody-dependent enhancement (ADE) of infection and the other is vaccine-associated enhanced respiratory disease (VAERD). ADE phenomenon conditions the presence of non-neutralizing or sub-neutralizing antibodies, which bind to the virus particles. Virus-antibody immune complexes are internalized into host cells via interaction of the antibody Fc region with the cellular Fc receptors $(30,32)$. So, in ADE mechanism the target cells are myeloid lineage cells with Fc receptors expression. In contrast, SARS-CoV-2 primarily infects pulmonary, endothelial, renal, and intestinal parenchymal cells that express ACE2. Therefore, Fc receptor mediated ADE not only intensifies the infection of already susceptible cells but also can expand tropism to, e.g., monocytes and macrophages. Moreover, internalized immune complexes can cause suppression of the cellular innate antiviral response (32). In the consequence, this leads to the enhancement of viral replication and exacerbation of clinical symptoms. In some patients with COVID-19, approximately 7 th to 14 th day of illness a dramatic decline in respiratory function occurs. It is suggested that the pathomechanism of this phenomenon is similar to Fc receptor-mediated ADE, the formation of immune complexes may activate monocytes/macrophages to trigger a cytokine storm (32-34). The above data, and the earlier in vitro tests with the use of serum from SARS-CoV patients with $S$ protein-specific antibodies indicate that the therapeutic use of convalescents' plasma with anti-SARS-CoV-2 antibodies could facilitate infecting monocytes/macrophages and in the consequence cause disease exacerbation $(35,36)$. ADE has been described after immunizing cats with a vaccine against veterinary coronavirus $(37,38)$.

VAERD is a distinct clinical syndrome, it mainly occurs after the use of a vaccine containing conformationally incorrect antigens. VAERD may be the result of two major mechanisms of immunological phenomenon, which are associated with enhanced respiratory disease $(30,32)$. One of them is conditional upon immune complex formation and complement deposition in lungs tissue (in the presence of high viral load). Whereas the other is associated with complement activation, expression of proallergic cytokines and in the result, with the development of allergic inflammation (39). VAERD was demonstrated in humans immunized with vaccines for measles and respiratory syncytial virus (RSV) and in animals for SARS (40-42).

\section{Anti-SARS-CoV-2 drugs}

According to WHO (43), Centers for Disease Control and Prevention (CDC) (44), and the US Food and Drug Administration (FDA) (45), there is still no antiviral drug that could be useful in the prevention or therapy patients with early symptoms of COVID-19. Currently, 12 drugs are in clinical trials against COVID-19, registered by the WHO (46). Three drugs are in advanced clinical trials: remdesivir, chloroquine and hydroxychloroquine, granted with FDA emergency authorization for treatment of hospitalized patients with severe COVID-19 (47,48). On the other hand, the China International Exchange and Promotive Association for Medical and Health Care (CPAM) recommended, only in clinical trial, the use of lopinavir-ritonavir in hospitalized older patients 
with severe COVID-19 (49). Remdesivir is a novel, relatively safe compound, being a phosphoramidate, and constituting a prodrug. This compound is metabolized into its active form, and adenine nucleotide analogue that interferes with viral RNA - dependent RNA polymerase (RdRp) leading to inhibition of RNA synthesis. In vitro tests, as well as in animal experiments show that remdesivir may effectively inhibit SARS-CoV-2 infection in humans $(50,51)$. However, it is still uncertain whether remdesivir causes direct antiviral effect on the enhanced clearing of viral loads in the respiratory tract. Whereas chloroquine and hydroxychloroquine are drugs with many years' history of clinical use for the prophylaxis and treatment of malaria, and for the treatment of chronic $Q$ fever and various autoimmune diseases (52). In comparison to chloroquine, hydroxychloroquine is less toxic while it demonstrates similar activity. Those drugs demonstrate antiviral activity by interfering with glycosylation of ACE2 receptor and elevating the $\mathrm{pH}$ in endosomes. Both medicines can inhibit the SARS-CoV-2 cell entry (53-55). The presented clinical trials confirmed that the use of those drugs promote laboratory virus - negative conversion and shortening the course of COVID-19. However, certain adverse effects in patients treated for COVID-19 were described, such as retinopathy, neuromyopathy, nephromyopathy, and cardiomyopathy due to chloroquine/ hydroxychloroquine $(48,53)$. Whereas, lopinavir-ritonavir is a combination antiviral drug actively inhibiting viral protease, the enzyme that is essential for maturation in viral replication. Lopinavir-ritonavir is used for treatment of HIV-infected individuals, as it is characterized by high specificity for HIV protease (56). The activity of the drug, expressed through e.g. the reduction of viral load was also confirmed in patients infected with SARS-CoV (57). However, the randomized, controlled trial in adults hospitalized with severe COVID-19 has proven that lopinavir-ritonavir did not significantly accelerate clinical improvement, and did not reduce the viral load. On the other hand, gastrointestinal adverse events including nausea, vomiting, and diarrhea were more common consequences of lopinavir-ritonavir treatment (58).

Despite the undoubtful progress of research, the treatment of patients with SARS-CoV-2 infection is still mainly symptomatic.

\section{Interferon (IFN)}

Until now, there are no antiviral drugs or vaccine that have been claimed to be useful in the prevention or treatment of this disease. SARS-CoV-2 infection still poses a serious threat to the health and life of people all over the world. Therefore, it is necessary to implement a new anti-COVID-19 prevention strategy based on the induction of cellular antiviral activities. It is well known that SARS infection course may be symptoms free or mild/moderate. The percentage of such cases in children aged between 2-13 years is over $90 \%$ (21). Human population is naive to SARS-CoV-2. The lack of clinical symptoms of the disease or their minimization seems to be determined by the innate immunity activity restricting the development of viral infection and its pathogenicity. However, that activity does not completely ablate viral replication, SARS-CoV-2 is able to replicate to low, detectable levels, which would explain that such patients tested positive $(34,59)$.
In non-specific antiviral host defense the basic role is played by cellular IFN response. There are 3 types of IFN, whereas type I interferons (I IFN) including IFN- $\alpha$ (13 subtypes in humans) and singular IFN- $\beta$ have broad spectrum of antiviral activities $(60,61)$. IFN- $\alpha$ and IFN- $\beta$ are produced by almost all cells in response to viral infection. IFN $\alpha / \beta$ activity is expressed ultimately with an induction of a number of interferon-stimulated genes (ISGs) which encoded for a variety antiviral effectors (62). However, ex vivo tests showed that SARS-CoV-2 does not induce significant expression of any IFN in the infected human lung tissues (63). So, the development of productive SARS-CoV-2 infection may be a result of ineffective host IFN response. This conclusion is confirmed by tests in cultured cells, demonstrating strong reduction of SaRS-CoV-2 replication IFN- $\alpha$ and IFN- $\beta$ treatment at concentrations that are clinically achievable in patients $(64,65)$. The results prove SARS-CoV-2 sensibility to I IFN. In addition, high level of SARS-CoV-2 replication suppression may suggest that this virus, contrary to SARS-CoV, does not show the ability to modulate IFN activity in cells. IFN- $\alpha$ also induces innate autophagic response via autophagosome - lysosome fusion which probably inhibits SARS-CoV-2 (66). So, the above data indicate that I IFN enhances innate immunity to SARS-CoV-2 which helps to limit virus infection/dissemination. Its induction may be of special significance during COVID-19 incubation period. Therefore, the target is to urgently consider the use of I IFN in prophylaxis against COVID-19 in adult patients with high risk of SARS-CoV-2 infection, especially those who start quarantine isolation. In much earlier clinical, randomized, controlled trials on adults there was proven the possibility to use human IFN- $\alpha$-recombinant (rIFN- $\alpha$, nasal spray) or natural (nIFN- $\alpha$, oral lozenges) in prophylaxis against acute respiratory illness-ARI $(67,68)$. However, considerable limitation of ARI incidents was only confirmed in patients applying rIFN- $\alpha$ in nasal spray only. Currently, rIFN- $\alpha$ in aerosolized inhalation (novaferon) is subject to clinical trials. The results obtained so far indicate that this drug (applied twice a day for $15 \mathrm{~min}$ for 10 days) may be both effective and safe in COVID-19 prevention (69).

The recent research also document the inhibitory activity in vitro of type 3 IFN (IFN $\lambda$ ), especially to the replication of SARS-CoV-2 (70). However, this effect was dependent on the type of cell line used for experiments which requires further experimental works.

\section{Conclusion}

SARS-CoV-2 still demonstrates very high epidemic potential. The sanitary procedures applied are not sufficient to fight COVID-19. The effectiveness of the expected anti-COVID-19 vaccine may be unsatisfactory. Until now, it has been unclear which drug would be useful in the prevention or therapy of patients with early symptoms of COVID-19. Therefore it is justified to urgently consider the use of IFN- $\alpha$ (in aerosolized inhalation) in patients with high risk of SARS-CoV-2 starting the mandatory quarantine.

\section{Acknowledgements}

Not applicable. 


\section{Funding}

No funding was received.

\section{Availability of data and materials}

Not applicable.

\section{Authors' contributions}

AS-K wrote the manuscript. AS revised the manuscript. Both authors read and approved the final manuscript.

\section{Ethics approval and consent to participate}

Not applicable.

\section{Patient consent for publication}

Not applicable.

\section{Competing interests}

The authors declare that they have no competing interests.

\section{References}

1. World Health Organization (WHO): WHO Coronavirus Disease (COVID-19) Dashboard. https://covid19.who.int. Accessed September 4, 2020.

2. World Health Organization (WHO): Pneumonia of unknown cause - China. https://www.who.int/csr/don/05-january-2020-pn eumonia-of-unkown-cause-china/en/. Accessed January 5, 2020

3. World Health Organization (WHO): Novel coronavirus - China https://www.who.int/csr/don/12-january-2020-novel-coronaviruschina/en/. Accessed January 12, 2020

4. Zhou P, Yang XL, Wang XG, Hu B, Zhang L, Zhang W, Si HR, Zhu Y, Li B, Huang CL, et al: A pneumonia outbreak associated with a new coronavirus of probable bat origin. Nature 579 : 270-273, 2020

5. Huang C, Wang Y, Li X, Ren L, Zhao J, Hu Y, Zhang L, Fan G, $\mathrm{Xu} \mathrm{J}, \mathrm{Gu} \mathrm{X}$, et al: Clinical features of patients infected with 2019 novel coronavirus in Wuhan, China. Lancet 395: 497-506, 2020.

6. Cao Y, Liu X, Xiong L, Cai K: Imaging and clinical features of patients with 2019 novel coronavirus SARS-CoV-2. A systematic review and meta-analysis. J Med Virol: April 3, 2020 (Epub ahead of print)

7. Heydari K, Rismantab S, Shamshirian A, Lotfi P, Shadmehri N, Houshmand P, Zahedi M, Shamshirian D, Bathaeian S and Alizadeh-Navaei R: Clinical and Paraclinical Characteristics of COVID-19 patients: A systematic review and meta-analysis. medRxiv: doi: https://doi.org/10.1101/2020.03.26.20044057.

8. Johns Hopkins University and Medicine: Coronavirus Resourse Center. https://coronavirus.jhu.edu. Accessed March 13, 2020.

9. World Health Organization (WHO): Archived: WHO Timeline - COVID-19. https://www.who.int/news/item/27-042020-who-timeline---covid-19. Accessed April 27, 2020.

10. Wu YCh, Chen CS and Chan YJ: The outbreak of COVID-19: An overview. J Chin Med Assoc 83: 217-220, 2020.

11. Johns Hopkins University and Medicine: Coronavirus Resourse Center. https://coronavirus.jhu.edu. Accessed September 3, 2020.

12. Zhu N, Zhang D, Wang W, Li X, Yang B, Song J, Zhao X Huang B, Shi W, Lu R, et al; China Novel Coronavirus Investigating and Research Team: A novel coronavirus from patients with pneumonia in China, 2019. N Engl J Med 382: 727-733, 2020.

13. Szkaradkiewicz-Karpińska $A$ and Baksalary-Iżycka K: SARS-CoV-2 infection - spread and pathogenicity. J Pre Clin Res. 14: 49-51, 2020.
14. Wu F, Zhao S, Yu B, Chen YM, Wang W, Song ZG, Hu Y, Tao ZW, Tian JH, Pei YY, et al: A new coronavirus associated with human respiratory disease in China. Nature 579: 265-269, 2020.

15. Lu R, Zhao X, Li J, Niu P, Yang B, Wu H, Wang W, Song H, Huang B, Zhu N, et al: Genomic characterisation and epidemiology of 2019 novel coronavirus: Implications for virus origins and receptor binding. Lancet 395: 565-574, 2020.

16. Tortorici MA and Veesler D: Structural insights into coronavirus entry. Adv Virus Res 105: 93-116, 2019.

17. Hoffmann M, Kleine-Weber H, Schroeder S, Krüger N, Herrler T, Erichsen S, Schiergens TS, Herrler G, Wu N-H, Nitsche A, et al: SARS-CoV-2 cell entry depends on ACE2 and TMPRSS2 and is blocked by a clinically proven protease inhibitor. Cell 181: 271-280.e8, 2020.

18. Peiris JSM, Yuen KY, Osterhaus AD, Stöhr K and Stöhr K: The severe acute respiratory syndrome. N Engl J Med 349: 2431-2441, 2003.

19. Lipsitch M, Cohen T, Cooper B, Robins JM, Ma S, James L, Gopalakrishna G, Chew SK, Tan CC, Samore MH, et al: Transmission dynamics and control of severe acute respiratory syndrome. Science 300: 1966-1970, 2003.

20. Liang G, Chen Q, Xu J, Liu Y, Lim W, Peiris JSM, Anderson LJ, Ruan L, Li H, Kan B, et al; SARS Diagnosis Working Group: Laboratory diagnosis of four recent sporadic cases of community-acquired SARS, Guangdong Province, China. Emerg Infect Dis 10: 1774-1781, 2004.

21. Ortiz-Prado E, Simbaña-Rivera K, Gómez-Barreno L, Rubio-Neira M, Guaman LP, Kyriakidis NC, Muslin C, Jaramillo AMG, Barba-Ostria C, Cevallos-Robalino D, et al: Clinical, molecular, and epidemiological characterization of the SARS-CoV-2 virus and the Coronavirus Disease 2019 (COVID-19), a comprehensive literature review. Diagn Microbiol Infect Dis 98: 115094, 2020.

22. Sanche S, Lin YT, Xu C, Romero-Severson E, Hengartner N and Ke R: High contagiousness and rapid spread of severe acute respiratory syndrome coronavirus 2 . Emerg Infect Dis 26: 1470-1477, 2020

23. Tong ZD, Tang A, Li KF, Li P, Wang HL, Yi JP, Zhang YL and Yan JB: Potential Presymptomatic Transmission of SARS-CoV-2, Zhejiang Province, China, 2020. Emerg Infect Dis 26: 1052-1054, 2020.

24. World Health Organization (WHO): Draft landscape of COVID-19 candidate vaccines. http//www.who. $\mathrm{int} / \mathrm{publications} / \mathrm{m} /$ item/draft-landscape-of-covid-19-candidatevaccines. Accessed September 3, 2020.

25. Calina D, Docea AO, Petrakis D, Egorov AM, Ishmukhametov AA, Gabibov AG, Shtilman MI, Kostoff R, Carvalho F, Vinceti M, et al: Towards effective COVID 19 vaccines: Updates, perspectives and challenges (Review). Int J Mol Med 46: 3-16, 2020.

26. Ertl HCJ: The ideal vaccine: Until death do us part. Mol Ther 19: 820-822, 2011

27. Hoft DF, Brusic V and Sakala IG: Optimizing vaccine development. Cell Microbiol 13: 934-942, 2011.

28. Diamond MS and Pierson TC: The challenges of vaccine developmentagainst a new virus during a pandemic. Cell Host Microbe 27: 699-703, 2020.

29. Bottazzi ME, Strych U, Hotez PJ and Corry DB: Coronavirus vaccine-associated lung immunopathology-what is the significance? Microbes Infect: June 26, 2020 (Epub ahead of print).

30. Graham BS: Rapid COVID-19 vaccine development. Science 368: 945-946, 2020.

31. Burton DR and Walker LM: Rational vaccine design in the time of COVID-19. Cell Host Microbe 27: 695-698, 2020.

32. Moore JP and Klasse PJ: COVID-19 Vaccines: "Warp Speed" Needs Mind Melds, Not Warped Minds. J Virol 94: e01083-e20, 2020.

33. Yip MS, Leung HL, Li PH, Cheung CY, Dutry I, Li D, Daëron M, Bruzzone R, Peiris JS and Jaume M: Antibody-dependent enhancement of SARS coronavirus infection and its role in the pathogenesis of SARS. Hong Kong Med J 22 (Suppl 4): 25-31, 2016.

34. Vabret N, Britton GJ, Gruber C, Hegde S, Kim J, Kuksin M, Levantovsky R, Malle L, Moreira A, Park MD, et al; Sinai Immunology Review Project: Immunology of COVID-19: Current state of the science. Immunity 52: 910-941, 2020.

35. Klasse PJ: Neutralization of virus infectivity by antibodies: Old problems in new perspectives. Adv Biol 2014: 1-24, 2014. 
36. de Alwis R, Chen S, Gan ES and Ooi EE: Impact of immune enhancement on Covid-19 polyclonal hyperimmune globulin therapy and vaccine development. EBioMedicine 55: 102768 , 2020.

37. Vennema H, de Groot RJ, Harbour DA, Dalderup M, Gruffydd-Jones T, Horzinek MC and Spaan WJ: Early death after feline infectious peritonitis virus challenge due to recombinant vaccinia virus immunization. J Virol 64: 1407-1409, 1990.

38. Olsen CW, Corapi WV, Ngichabe CK, Baines JD and Scott FW: Monoclonal antibodies to the spike protein of feline infectious peritonitis virus mediate antibody-dependent enhancement of infection of feline macrophages. J Virol 66: 956-965, 1992.

39. Bolles M, Deming D, Long K, Agnihothram S, Whitmore A Ferris M, Funkhouser W, Gralinski L, Totura A, Heise M, et al: A double-inactivated severe acute respiratory syndrome coronavirus vaccine provides incomplete protection in mice and induces increased eosinophilic proinflammatory pulmonary response upon challenge. J Virol 85: 12201-12215, 2011.

40. Polack FP, Teng MN, Collins PL, Prince GA, Exner M, Regele H, Lirman DD, Rabold R, Hoffman SJ, Karp CL, et al: A role for immune complexes in enhanced respiratory syncytial virus disease. J Exp Med 196: 859-865, 2002.

41. Polack FP, Hoffman SJ, Crujeiras G and Griffin DE: A role for nonprotective complement-fixing antibodies with low avidity for measles virus in atypical measles. Nat Med 9: 1209-1213, 2003.

42. Graham BS, Henderson GS, Tang YW, Lu X, Neuzil KM and Colley DG: Priming immunization determines T helper cytokine mRNA expression patterns in lungs of mice challenged with respiratory syncytial virus. J Immunol 151: 2032-2040, 1993.

43. World Health Organization (WHO): Clinical management of COVID-19, interim guidance. http//www.who.int/publications/ $\mathrm{i} /$ item/clinical-management-of-covid-19. Accessed May 27, 2020

44. Centers for Disease Control and Prevention (CDC): Interim clinical guidance for management of patients with confirmed coronavirus disease (COVID-19). https//www.cdc. gov/coronavirus/2019-ncov/hcp/clinical-guidance-management -patients.html. Accessed June 30, 2020.

45. U.S. Food and Drug Administration (FDA): Coronavirus disease 2019 (COVID-19). https//www.fda.gov/emergencypreparedness-and-response/counterterrorism-and-emerging threats-and-coronavirus disease 2019 (COVID-19). Accessed September 3, 2020.

46. World Health Organization (WHO): Landscape analysis of therapeutics as 21st March 2020. https://www.who. $\mathrm{int} / \mathrm{blueprint/priority-diseases/key-action/Table} \mathrm{of} \mathrm{therapeutics}$ Appendix_170220.pdf?ua=1. Accessed March 21, 2020.

47. US Food and Drug Administration: Coronavirus (COVID-19) Update: FDA issues emergency use authorization for potential COVID-19 treatment. https://www.fda gov/news-events/press-announcements/coronavirus-covid-19-up date-fda-issues-emergency-use-authorization-potential-covid-19 -treatment. Accessed May 1, 2020.

48. Wu R, Wang L, Kuo HD, Shannar A, Peter R, Chou PJ, Li S, Hudlikar R, Liu X, Liu Z, et al: An update on current therapeutic drugs treating. Curr Pharmacol Rep 6: 1-15, 2020.

49. Diagnosis and Treatment Protocol for COVID-19: (Trial version 7) issued by the General Office of the National Health Commission and the Office of the National Administration of Traditional Chinese Medicine. http://www.chinacdc. cn/en/COVID19. Accessed May 6, 2020.

50. Wang M, Cao R, Zhang L, Yang X, Liu J, Xu M, Shi Z, Hu Z, Zhong W and Xiao G: Remdesivir and chloroquine effectively inhibit the recently emerged novel coronavirus $(2019-\mathrm{nCoV})$ in vitro. Cell Res 30: 269-271, 2020.

51. McKee DL, Sternberg A, Stange U, Laufer $S$ and Naujokat C: Candidate drugs against SARS-CoV-2 and COVID-19. Pharmacol Res 157: 104859, 2020.

52. Ben-Zvi I, Kivity S, Langevitz $P$ and Shoenfeld $Y$ : Hydroxychloroquine: From malaria to autoimmunity. Clin Rev Allergy Immunol 42: 145-153, 2012.
53. Gao J, Tian Z and Yang X: Breakthrough: Chloroquine phosphate has shown apparent efficacy in treatment of COVID-19 associated pneumonia in clinical studies. Biosci Trends 14: 72-73, 2020.

54. Pereira BB: Challenges and cares to promote rational use of chloroquine and hydroxychloroquine in the management of coronavirus disease 2019 (COVID-19) pandemic: A timely review. J Toxicol Environ Health B Crit Rev 23: 177-181, 2020.

55. Colson P, Rolain JM, Lagier JC, Brouqui P and Raoult D: Chloroquine and hydroxychloroquine as available weapons to fight COVID-19. Int J Antimicrob Agents 55: 105932, 2020.

56. Corbett AH, Lim ML and Kashuba AD: Kaletra (lopinavir/ ritonavir). Ann Pharmacother 36: 1193-1203, 2002.

57. Chu CM, Cheng VC, Hung IF, Wong MM, Chan KH, Chan KS, Kao RY, Poon LL, Wong CL, Guan Y, et al; HKU/UCH SARS Study Group: Role of lopinavir/ritonavir in the treatment of SARS: Initial virological and clinical findings. Thorax 59: 252-256, 2004

58. Cao B, Wang Y, Wen D, Liu W, Wang J, Fan G, Ruan L, Song B, Cai Y, Wei M, et al: A Trial of lopinavir-ritonavir in adults hospitalized with severe Covid-19. N Engl J Med 382: 1787-1799, 2020.

59. Li N, Wang P, Wang X, Geng C, Chen J and Gong Y: Molecular diagnosis of COVID-19: Current situation and trend in China (Review). Exp Ther Med 20: 13, 2020.

60. Smith PL, Lombardi G and Foster GR: Type I interferons and the innate immune response - more than just antiviral cytokines. Mol Immunol 42: 869-877, 2005.

61. George $\mathrm{J}$ and Mattapallil JJ: Interferon- $\alpha$ subtypes as an adjunct therapeutic approach for human immunodeficiency virus functional cure. Front Immunol 9: 299, 2018.

62. Goodbourn S, Didcock L and Randall RE: Interferons: Cell signalling, immune modulation, antiviral response and virus countermeasures. J Gen Virol 81: 2341-2364, 2000.

63. Chu H, Chan JF, Wang Y, Yuen TTT, Chai Y, Hou Y, Shuai H, Yang D, Hu B and Huang X: Comparative replication and immune activation profiles of SARS-CoV-2 and SARS-CoV in human lungs: an ex vivo study with implications for the pathogenesis of COVID-19. Clin Infect Dis 71: 1400-1409, 2020.

64. Mantlo E, Bukreyeva N, Maruyama J, Paessler S and Huang C: Antiviral activities of type I interferons to SARS-CoV-2 infection. Antiviral Res 179: 104811, 2020.

65. Lokugamage KG, Hage A, Schindewolf C, Rajsbaum R and Menachery VD: Type I interferon susceptibility distinguishes SARS-CoV-2 from SARS-CoV. J Virol: September 16, 2020 (Epub ahead of print).

66. Shojaei S, Suresh M, Klionsky DJ, Labouta HI and Ghavami S: Autophagy and SARS-CoV-2 infection: Apossible smart targeting of the autophagy pathway. Virulence 11: 805-810, 2020.

67. Gao L, Yu S, Chen Q, Duan Z, Zhou J, Mao C, Yu D, Zhu W, Nie J and Hou Y: A randomized controlled trial of low-dose recombinant human interferons alpha- $2 \mathrm{~b}$ nasal spray to prevent acute viral respiratory infections in military recruits. Vaccine 28 : 4445-4451, 2010

68. Bennett AL, Smith DW, Cummins MJ, Jacoby PA, Cummins JM and Beilharz MW: Low-dose oral interferon alpha as prophylaxis against viral respiratory illness: A double-blind, parallel controlled trial during an influenza pandemic year. Influenza Other Respir Viruses 7: 854-862, 2013.

69. Zheng F, Zhou Y, Zhou Z, Ye F, Huang B, Huang Y, Ma J, Zuo Q, Tan X, Xie J, et al: SARS-CoV-2 clearance in COVID-19 patients with Novaferon treatment: A randomized, open-label, parallel-group trial. Int J Infect Dis 99: 84-91, 2020.

70. Felgenhauer U, Schoen A, Gad HH, Hartmann R, Schaubmar AR, Failing K, Drosten C and Weber F: Inhibition of SARS-CoV-2 by type I and type III interferons. J Biol Chem 295: 13958-13964, 2020. International (CC BY-NC-ND 4.0) License. 